\title{
Eclipse 2017
}

Barbara S. Giesser, MD

Neurology ${ }^{\circledR}$ 2018;91:44. doi:10.1212/WNL.0000000000005730

\section{Correspondence}

Dr. Giesser

BGiesser@mednet.ucla.edu

Tumor

Its malevolent moon

Moved across the cerebral sky

Blotting out your sun.

I am so lost

Without your light

Now my days are perpetually dark. 


\section{Neurology}

Eclipse 2017

Barbara S. Giesser

Neurology 2018;91;44

DOI 10.1212/WNL.0000000000005730

\section{This information is current as of July 2, 2018}

\section{Updated Information \&} Services

\section{Subspecialty Collections}

Permissions \& Licensing

\section{Reprints}

including high resolution figures, can be found at: http://n.neurology.org/content/91/1/44.full

This article, along with others on similar topics, appears in the following collection(s):

Primary brain tumor

http://n.neurology.org/cgi/collection/primary_brain_tumor

Information about reproducing this article in parts (figures,tables) or in its entirety can be found online at:

http://www.neurology.org/about/about_the_journal\#permissions

Information about ordering reprints can be found online:

http://n.neurology.org/subscribers/advertise

Neurology ${ }^{\circledR}$ is the official journal of the American Academy of Neurology. Published continuously since 1951, it is now a weekly with 48 issues per year. Copyright () 2018 American Academy of Neurology. All rights reserved. Print ISSN: 0028-3878. Online ISSN: 1526-632X.

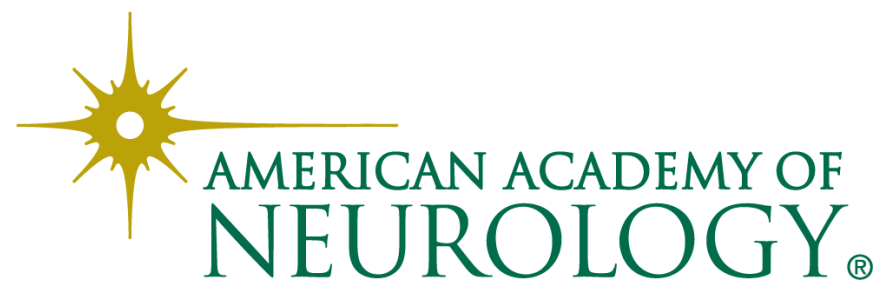

